McNicol, J.G. See: Timmerman, H. and J.G. McNicol.

Mitchell, Kenneth J. SYLVER: Modelling the impact of silviculture on yield, lumber value and economic return. 64(2): 127-131.

Moore, T. See: Baskerville, G.L. and T. Moore.

Morley, Peter M. Urban forestry in North York. 64(4): 360-364.

Morrow, Lorne D. Alternate strip clearcutting in upland black spruce. VII. Planning and implementation. 64(1): 64-69.

Murphy, Peter J. and Ralph W. Roberts. Forestry education in China. 64(6): 469-474.

Murphy, Peter J. See: Duffy, P.J.B. and Peter J. Murphy.

Murphy, Peter J. See: Herrick, Caron A. and Peter J. Murphy.

Nicolson, J.A. Alternate strip clearcutting in upland black spruce. $v$. The impact of harvesting on the quality of water flowing from small basins in shallow-soil boreal ecosystems. 64(1): 52-58.

Oldford, Gordon C. Forestry/wildlife workshop. What's in the future: The timber management viewpoint. 64(3): 283-284.

Opper, Michael. Forestry/wildlife workshop. What's in the future? The forest industry viewpoint. 64(3): 280-282.

Paillé, Gilbert G. and Robert Deffrasnes. Le nouveau régime forestier du Québec. 64(1): 3-8.

Park, Y.S. See: Fowler, D.P., J.D. Simpson, Y.S. Park and M.H. Schneider.

Payne, D., J. McNicol, G. Eason and D. Abraham. Forestry/ wildlife workshop. Moore management and timber management: Three case studies. 64(3): 270-276.

Phillips, William E., Glen W. Armstrong, James A. Beck and Kamal Banskota. The opportunity cost of forest land losses to agricultural uses: An Alberta case study. 64(1); 35-39.

Pollard, D.F.W. See: Edwards, D.G.W., D.F.W. Pollard and B.S.P. Wang.

Power, J.M. Decision support systems for the Forest Insect and Disease Survey and for pest management. 64(2): 132-135.

Preiss, Stephen W. See: Walker, H. Douglas and Steven W. Preiss.

Ray, P.N. See: Timmer, V.R. and P.N. Ray.

Schneider, M.H. See: Fowler, D.P., J.D. Simpson, Y.S. Park and M.H. Schneider.

Shidong, Zhao. See: Burger, D. and Zhao Shidong.

Simpson, J.D. See: Fowler, D.P., J.D. Simpson, Y.S. Park and M.H. Schneider.

Sims, Richard A. and William D. Towhill. Alternate strip clearcutting in upland black spruce. VIII. Shallow-soil ecosystems and their classification. 64(1): 70-75.

Skeates, D.A. See: Haavisto, V.F., R.L. Fleming and D.A. Skeates.
Smith, J.H.G. Don't let early impressions diminish long-run profit potentials. 64(4): 365-366.

Smyth, Jack H. See: Johnson, John D. and Jack H. Smyth.

Stiell, W.M. Consistency of cone production in individual red pine. 64(6): 480-484.

Straight, William. Forestry/wildlife workshop. Resource management policies and guidelines - workshop discussion. 64(3): 287.

Thirgood, J.V. Present realities and future possibilities for forestry education. 64(5): 434-436.

Thompson, I.D. Forestry/wildlife workshop. Habitat needs of furbearers in relation to logging in boreal Ontario. 64(3); 251-261.

Timmer, V.R. and P.N. Ray. Evaluating soil nutrient regime for black spruce in the Ontario claybelt by fertilization. 64(1): 40-46.

Timmerman, H.R. and J.G. McNicol. Forestry/wildlife workshop. Moose habitat needs. 64(3): 238-245.

Titus, Stephen J. and W.S. Adams. A fifth generation approach to problem-solving in forest mensuration and sampling. 64(3): 186-189.

Towhill, William D. See: Sims, Richard A. and William D. Towhill.

Van Wagner, C.E. The historical pattern of annual burned area in Canada. 64(3): 182-185.

Vézina, Paul-E. and Hélène Falardeau. Le développement de peuplements de conifères sur une période de 50 ans après la coupe. 64(4): 329-333.

Waines, A.C. See: Arnott, J.T., W.W. Carr and A.C. Waines.

Walker, H. Douglas and Stephen W. Preiss. Operational planning using mixed integer programming. 64(6): 485-488.

Wang, B.S.P. See: Edwards, D.G.W., D.F.W. Pollard and B.S.P. Wang.

Welsh, D.A. Forestry/wildlife workshop. Meeting the habitat needs of non-game forest wildlife. 64(3): 262-266.

Whitney, R.D. Armillaria root-rot damage in softwood plantations in Ontario. 64(4): 345-351.

Winterton, G.K. Forestry/wildlife workshop. What's in the future? The wildlife management viewpoint. 64(3): 285-286.

Wood, J.E. and S.W.J. Dominy. Mechanical site preparation and early chemical tending in white spruce: 19-year results. 64(3): 177-181.

Zimmerman, Adam H. Forestry/wildlife workshop. Forestry and wildlife - uncomfortable bedfellows? Part II. 64(3): 279.

\title{
Reviewers - The Forestry Chronicle, Volume 64, 1988
}

In addition to thanking the Associate Editors, I wish to thank the following reviewers and apologize to those whose names I have missed.
J.T. Arnolt
J.A. Beck
J.-C. Boivin
T. Boyle
G. Couture
T. Cunia
R.B. Dickison
L. Doruis
M. Feller
A. Funk
R.L. Galloway
J.-N. Girard
M.D. Haydon
Y. Hiratsuka
B. Janz
C. de Kimpe
R. Lachance
Y. Lamontagne
R.A. Lapointe
G. La Rocque
D. Lavender
S. Magnussen
K. Maret
J. Mervart
G. Miller
G. Milne

The Editor

D.J. Morgan

M.J. Morgenstern

J. Nautiyal

R. Pagé

G.R. Parker

R.V. Quenet

K. Rymer

J.-P. Saucier

H. Schreier

G. Sheedy

R. Shepherd

N. Smith

G. Steneker
D. Tait

A. Teskey

J.-P. Thibault

V. Timmer

S.J. Titus

M. Villeneuve

G. Warren

D.H. Webster

R. Whitney

R.J. Woodham

J. Worral 